\title{
Publics, issues, and nanotechnology in Indian news media
}

\author{
Koen Beumer ${ }^{1,2 *}$ \\ ${ }^{1}$ Science and Society Group, University of Groningen, Groningen, ${ }^{2}$ Department of Technology and Society Studies, Maastricht University, \\ Maastricht, The Netherlands
}

\begin{abstract}
This article explores the relation between nanotechnology and the public in India. Nanotechnology is expected to have far-reaching consequences for developing countries and India has been particularly active in supporting the technology. This article contributes to the emerging literature on nanotechnology and the public by using a concept of the public that diverges from conventional accounts. Rather than assuming the public view coincides with the average opinion of the population of a certain territory, this article uses a concept of the public that was developed by the pragmatist philosopher, John Dewey, who defines the public in relation to the issue at hand. As an experiment, this article empirically studies the views of issue-based publics by analyzing the nanotechnology coverage of the Times of India. A total of 273 articles were identified between 2000 until 2010. The findings suggest that the main issue is the concern of missing out on the benefits of nanotechnology, in particular for various social groups in India and for the country itself. The view of the issue-based public is that more care is required for the positive consequences of nanotechnology to land in India.
\end{abstract}

Keywords: Dewey, India, issues, nanotechnology, newspaper, publics

\section{INTRODUCTION}

Discussions about emerging technologies abound with references to the public. For instance in the case of nanotechnology, it is now commonly accepted that the public acceptance of nanotechnology is an important prerequisite for the technology to be developed in a responsible manner. ${ }^{[1,2]}$ The public has entered the stage as a new actor in the governance of nanotechnology and "talk about the public (and, to an extent, talk with the public) has become a significant policy requirement."[3] However, who exactly is this "public" that is deemed so important?

*Address for correspondence:

E-mail: k.beumer@rug.nl

\begin{tabular}{|l|l|}
\hline \multicolumn{2}{|c|}{ Access this article online } \\
\hline Quick Response Code: & \\
\hline & Website: \\
\hline & www.jscires.org \\
& \\
\hline
\end{tabular}

In the past decades, scholars have employed various methods to assist in taking into account the view of the public in the governance of nanotechnology, ranging from opinion polls to newspaper analysis and public engagement activities. What these studies share is that they operate a notion of the public that assumes "the public" represents the average inhabitant of a particular territory, usually a country (see the next section). This article instead explores the relation between nanotechnology and the public using a different concept of the public: A concept of the public that is not defined by its representativeness of the entire population, but that is defined in relation to the issue at stake. As an experiment, this article aims to make this notion of the public operational for quantitative analysis

This is an open access article distributed under the terms of the Creative Commons Attribution-NonCommercial-ShareAlike 3.0 License, which allows others to remix, tweak, and build upon the work non-commercially, as long as the author is credited and the new creations are licensed under the identical terms.

For reprints contact: reprints@medknow.com

How to cite this article: Beumer K. Publics, issues, and nanotechnology in Indian news media. J Sci Res 2015;4:143-52. 
by analyzing the co-construction of publics and issues in the Indian newspaper press.

\section{CONCEPTUALIZING THE PUBLIC}

Several developments, over the last 30 years, have increased the importance of the public in the governance of science and technology. People around the world have become better educated and more vocal; several high-profile scandals around scientific and technological developments that harmed the public trust in the authority of scientists and politicians revealed the influence publics could exercise on issues of technological choice and governance; and, at least since the 1990s, there have been various calls for the democratization of science and technology, drawing on the basic insight that if science and technology exercise an influence on society that these should not be left in the hand of scientists and engineers alone. As a result of these developments, public support to science and technology has become both more important and less evident.

Parallel to these societal developments, scholars have turned their attention to the public. These studies range from attempts to elicit the public view on nanotechnology, for instance with the use of opinion polls or focus groups ${ }^{[4-8]}$ or by analyzing the way nanotechnology is framed in the newspapers ${ }^{[9-17]}$ to more pro-active studies that actively try to involve the public in the development and governance of nanotechnology..$^{[18-21]}$

While the views of the public are central to these studies, they often take for granted who counts as a member of the public. This has recently been criticized by constructivist scholars arguing that the public is actively shaped in the process of studying it. For instance, Maja Horst and Alan Irwin have shown in several studies of public engagement activities that, depending on the issues at stake, the public has been defined by opposing it to experts, to stakeholders, or by referring to consumers or national identities. ${ }^{[22-24]}$ Rather than being "out there," waiting to be discovered, these scholars point out that the public is actively shaped in the process of studying it. As Michae ${ }^{[25]}$ nicely puts it, publics: "Are also being 'made' as particular types of citizens by virtue of the models of the public that inform public engagement with science initiatives. Arguably, as these studies have shown, such models are mediated by the form of public engagement: Assumptions about what the public should (or can) do (or be) are 'built into' the techniques by which their voice is encouraged to find 'expression”" (p. 619).
The public that is "made" by those studying the views of the public usually is a unified public. While often not explicitly providing a definition of the public, "the public" is generally constructed as an actor who is representative for the inhabitants of a particular territory, usually a country. Newspaper analyses for instance construct such a public when choosing to study national newspapers and by studying newspapers that are read by a representative set of the national population. Moreover, public engagement activities regularly construct the public in this way when recruiting so-called "blank slate" participants - participants with no stake in the development of the technology and little prior knowledge of the technology in question. The rationale is that factors such as having prior knowledge about the technology or having a stake in the technology in question are not representative for the general populace.

That this notion of the public is not self-evident also becomes clear when we associate it to particular models of democracy. One could, for instance, argue that newspaper analyses, by directly mapping media content onto the public opinion, presuppose the centrality of a unified public opinion, which is often associated with republican models of democracy. ${ }^{[26]}$ One could also argue that this direct mapping presupposes a view of the public that is easily manipulated and directly buys into whatever they are told by the media, a concern that has occupied scholars of democracy at least since Plato and that is nowadays often associated with Schumpeterian notions of democracy. ${ }^{[26]}$ Just like these democratic models can be contested so can their underlying notions of the public.

One particularly pertinent limitation to this concept of the public is that the unified public may not be so well-suited to capture a public whose views diverge. Several scholars have demonstrated the importance of taking into account such "divided" (or multiple) publics with case studies of technological controversies in which members of the public themselves have protested against equating "the public" with "the average inhabitant." For instance in analyzing public engagement activities for nanotechnology in Austria, Felt and Fochler ${ }^{[27]}$ show how the participants appropriate, resist, and transform the roles and identities that are ascribed to them in various public engagement settings. Others have drawn attention to instances in which "counter-publics" have been constructed in response to the dominant construction of a unified public. ${ }^{[25,28]}$ In other words, the unified public who is deemed representative for the average inhabitant of a country, without prior knowledge or stake in the technology in question, does 
not always coincide with the public that will actually voice their concerns. When one is interested in improving the democratic process and incorporating public concerns, then a different concept of the public is needed.

As an experiment, this article aims to make operational a concept of the public that may be better suited for these purposes: A concept of the public that revolves around the issue at hand. This issue-oriented concept of the public recently made headways in Science and Technology Studies ${ }^{[29,30]}$ and finds its origin with the American pragmatist philosopher John Dewey. Writing around the turn of the $20^{\text {th }}$ century, Dewey's main concern was to find a place for democracy in highly industrialized societies where expert-knowledge takes an increasingly central place in decision-making - a concern that is very much at the heart of contemporary discussions about the democratization of science and technology.

According to Dewey, "the public consists of all those that are affected by the indirect consequences of transactions to such an extent that it is deemed necessary to have those consequences systematically cared for." [31] At the basis of the concept lies a distinction between the public and the private, a line that is drawn on the basis of the extent and scope of the consequences. When two parties engage in a transaction that has consequences for them alone, Dewey calls it a private act. However, when the transaction of those two parties has consequences for other parties, and those consequences are so important that they should be taken care of, and then a public "comes into being." While this definition does not necessarily turn the public into a stakeholder, since it is only impacted by indirect consequences, the definition does potentially allow for the public to consist of actors who have an interest or possess knowledge about the issue at stake.

In this account, the public is not conceptualized as representative but as consisting of those parts of a population that are affected by the indirect consequences of private transactions; the public is not conceptualized as being "out there" but as being formed in the process of technological developments; and the public is not conceptualized as unified but as potentially diverse, as the same technological developments can have very different consequences for different groups, thus bringing into being multiple publics. As an experiment, this article aims to make this notion of the public operational for quantitative analysis. This provides a method for identifying what publics are brought into being that is based on a Dewey's notion of democracy. Before explaining the methodology, however, I briefly explain the case of nanotechnology in India.

\section{CONTEXT OF THIS STUDY}

Nanotechnology is usually defined as the understanding and control of matter at the nanoscale $\left(10^{-9} \mathrm{~m}\right)$. At this scale, material can gain new properties that can be used in a myriad of applications which are expected to have pervasive societal consequences. When the United States announced in 2000 that they would annually invest billions of dollars in the technology, they justified their spending by claiming that nanotechnology can herald a new industrial revolution. ${ }^{[32]}$ Considering this broad impact, various scholars have investigated the relation between nanotechnology and the public as was highlighted in the previous section. ${ }^{[4,9,18]}$

What most of these studies share, besides the use of a particular concept of the public, is an almost exclusive focus on Europe and Northern America. The topic of these studies is the relation between science, technology, and the public as situated in the Western societies.

This can partly be understood with reference to the fact that the majority of investments into nanotechnology are made by governments and companies in the "West." However, nanotechnology can also affect publics in the global South. Several scholars have for instance pointed out that the concentration of nanotechnology activities in the "West" may aggravate existing global inequalities. Nanotechnology may thus lead to what has been called a "nanodivide." ${ }^{[33,34]}$ Moreover, others have drawn attention to the promising role that nanotechnologies may play in solving development-related issues. Particularly, water, energy, health, and agriculture have been singled out as areas where nanotechnology may be used to develop new products that are directly beneficial to the poor, for instance through the development of nanotechnology-enabled water filters, drug-delivery mechanisms, solar cells, and fertilizers. ${ }^{[35,36]}$

Furthermore, developing countries themselves have developed nanotechnology initiatives themselves. Countries in Africa, Asia, and Latin America have made substantive investments in the field of nanotechnology, and some are even said to be world leaders in the field. ${ }^{[37-40]}$ India, for one, has been systematically investing in nanotechnology since 2002 and has become the 
sixth most prolific country in terms of nanotechnology publications, ahead of countries such as The Netherlands and England. ${ }^{[41]}$ Research on nanotechnology in India has addressed issues including the governance of risks, laboratory practices, public-private partnerships, and the benefits for development objectives; ${ }^{[42-45]}$ each building on the view that nanotechnology can thus affect "developed" countries as much as it can affect "developing" countries. However, the public in the latter has thus far escaped the attention of scholars. This article therefore studies the public of nanotechnology in the global South by focusing on the case of India which has become particularly active in nanotechnology over the last decade.

\section{METHODOLOGY AND SOURCES}

How can we explore the views of the public when using an issue-based concept of the public? There are no fixed ways in which issues are articulated. The articulation of issues is a highly-distributed process that can take place both in the domain of formal politics and in various subpolitical processes. ${ }^{[46]}$ In this perspective, newspapers offer a valuable starting point. Compared to other sources, newspapers potentially cover a broad variety of issues, making it a suitable source for analyzing the construction of issue-based publics.

This is particularly true for the Times of India which was selected as the most appropriate newspaper to investigate the construction of publics in India. In terms of both circulation and readership, the Times of India is the largest English-language newspaper in India, with a circulation of over 3 million copies and a readership of over 13 million. These readership numbers are not important because it should be representative for the public in India as a whole. The newspaper is not used as a proxy for the view of the average member of the public but as an indicator for the issues and publics that may emerge. The large readership numbers gain significance here because they may help to mitigate a potential restriction of using newspapers as a source stemming from their commercial nature. At present, commercial interests form an important driver for newspapers worldwide, including the Times of India, and this potentially results in a coverage bias toward those issues that will increase the number of sales. The large readership numbers gain significance here because they may entice the Times of India, more than other sources, to cover a wide range of issue, hence providing a valuable lens for exploring the construction of issue-based publics in India.
Nanotechnology articles were identified from the early days until January 1, 2010, 10 years after the launch of the American nanotechnology initiative that sparked the interest in nanotechnology worldwide. These articles were analyzed in line with the issue-based view of the public. As was mentioned above, Dewey defines the public as consisting of "those that are affected by the indirect consequences of transactions to such an extent that it is deemed necessary to have those consequences systematically cared for."[31] Based on this definition, I came up with the following empirically testable research question: For which third parties is nanotechnology said to have consequences that have to be systematically cared for? When applying this definition to the analysis of newspaper articles, it is derived that a public is constructed when nanotechnology (i) is said to have consequences; (ii) when those consequences affect actors not directly involved in the transaction; and (iii) when those consequences are sufficiently important to be said to require care. All newspaper articles were consequently coded along the lines of these three criteria.

The main difference with conventional newspaper analyses is that merely mentioning the impact of nanotechnology is not interpreted as indicative of the public views. In an issue-based account of the public, one can only speak of a public when the technology is said to have consequences for actors not directly involved in the transaction that are not sufficiently cared for. The benefit of making this issue-based concept of the public operational in this way is that it offers conceptual grip while simultaneously allowing for enough flexibility to let the framing of the particular public emerge from the empirical material. After all, which actors are said to be affected by the indirect consequences of nanotechnology, what nature is of the consequences that give rise to a particular public, and what measures have to be taken, remain questions that are open to empirical investigation.

It should be noted that the indirect consequences that can give rise to a public can be both positive and negative. Although it has often been presupposed that Dewey's definition of the public exclusively focuses on the negative consequences for publics, in fact, his definition leaves room for positive consequences as well. For instance, it can be hypothesized that nanotechnology will have positive consequences for third parties that are deemed so important that care is required to support the realization of those positive consequences. In several countries, governmental nanotechnology policies are for instance informed by the 
desire to strengthen national industries; whereas these policies are usually directed toward companies, it is the (beneficial) indirect consequences for the public that make this deem worthy of governmental support. Although even these measures will likely be negatively phrased, positive consequences can be a matter of concern when abstaining from action results in losing out on the benefits; these nevertheless concern issues about positive consequences. Dewey himself explicitly hints at this when he notes that he writes about "the consequences which are so important as to need control, whether by inhibition or by promotion." [31]

The articles were found using the advanced search function on the Times of India website as this was found to provide the most comprehensive results compared to other search strategies. Nanotechnology can be described with various terms, such as "nano," "nanoscience," and "research at the nanoscale." To ensure that all articles covering nanotechnology had included, I searched the online archive of the Times of India using the keywords "nano" and "nano*." Until January 1, 2010, a total of 273 articles were identified, after excluding articles that did not deal with nanotechnology but, for instance, covered the Tata Nano, the iPod Nano, and sodium nitrite. Articles that do not have nanotechnology as their primary topic were included because these can also give meaning to the technology. What issue-based public did these articles give rise to?

\section{ANALYSIS}

\section{Publics and Domains}

The first article mentioning nanotechnology in the Times of India appeared on August 1, 2001, only a few months before the Government of India first started investing in nanotechnology. ${ }^{[41]}$ The article mentions that an Israeli company developed a camera pill with the use of nanotechnology that can help searching for cancer in the intestines. Until late 2005, nanotechnology was scantly mentioned, after which a steady increase can be witnessed. In 2004, nanotechnology was mentioned in only two articles; whereas in 2008, 58 articles spoke about nanotechnology and 107 articles mentioned nanotechnology in 2009 [Figure 1].

Following Dewey's concept of the public, it is possible to distinguish between articles that do and do not give rise to a public. Although all articles mention nanotechnology, no public is constituted unless the article notes that actors not directly involved in nanotechnology transactions are

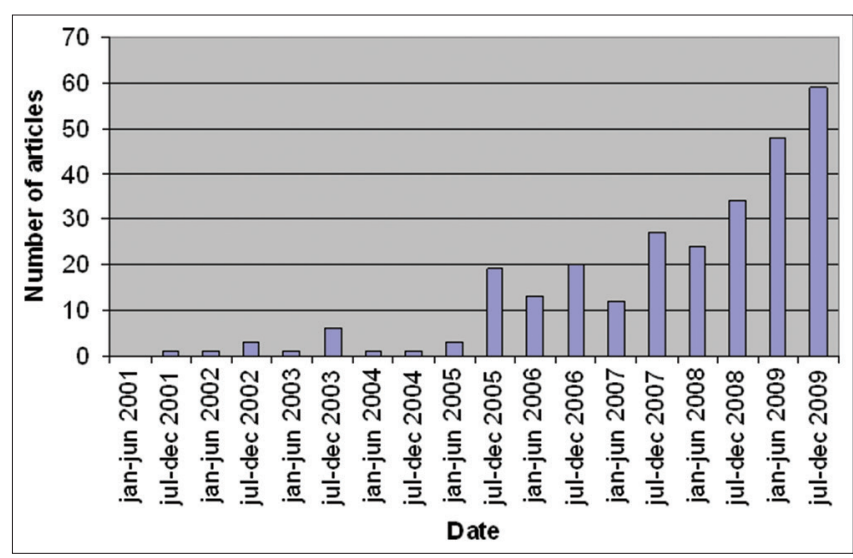

Figure 1: Number of articles over time

affected by the consequences of those transactions and when it is deemed necessary to have those consequences cared for. Figure 2 shows the distribution of articles over time that do and do not construct a public.

In the early 2000s, when the number of articles was still low, some arguments were made that the consequences of nanotechnology required systematic care. As the number of times nanotechnology was mentioned increased, the share of articles that did not constitute a public gained the upper hand but, from 2007 onward, a steep increase in the concern over nanotechnology is visible up to the point that, at the end of 2009, there are more articles in which a public is constructed than articles in which no public is constructed. One possible explanation for this increase in the articulation of issues (both positive and negative) could be the launch in 2007 the Nano Mission, a major governmental investment scheme in nanotechnology. As the government started investing more money into the technology, more researchers traditionally working in fields such as physics and chemistry started talking about their work as being nanotechnology and more debate ensued. ${ }^{[41]}$

In most articles, no specific domain of application is specified, and nanotechnology is described in general terms [Figure 3]. For instance, a 2007 article simply mentions that President Abdul Kalam would give several lectures on nanotechnology, and the article does not specify the applications that the president would discuss. ${ }^{[4]}$ Articles that do discuss fields of application mostly focus on nanotechnology in relation to health, which accounts for almost a quarter of the articles. For example, a 2005 article discusses various ways, in which nanotechnology can benefit cancer patients by improving methods for treating cancer. ${ }^{[48]}$ Other domains that are frequently discussed are energy and electronics that are discussed by only 


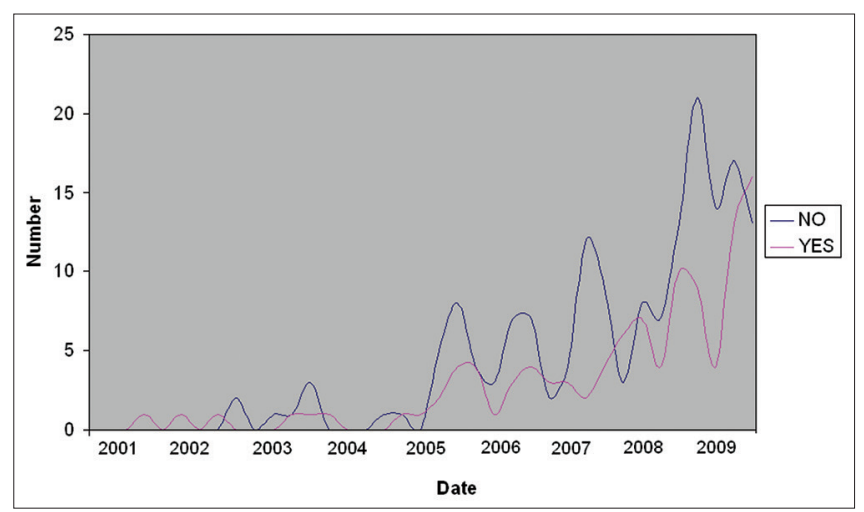

Figure 2: Distribution of publics over time

$7 \%$ and $6 \%$ of the articles, respectively. It is remarkable that very little attention is given to nanotechnology in relation to water which is one of the central topics in literature on nanotechnology and developing countries. ${ }^{[35,36]}$ Furthermore, little attention is given to agriculture $-<3 \%$, despite it being an important sector in India.

When splitting these results into whether a public comes into being or not, the results correspond with the overall distribution of domains of application. The great majority of issues are articulated in relation to nanotechnology in general or in relation to nanotechnology for health. However, as can be seen in Figure 4, in both cases, the share of articles that does not construct a public is larger. The only areas where the majority of the articles note nanotechnology has indirect consequences that require care are energy, water, materials, and the environment.

\section{Negative Consequences}

As was mentioned, the consequences that can give rise to publics can be both positive and negative. The Times of India portrays nanotechnology in an overwhelmingly positive manner. Negative consequences of nanotechnology are only mentioned in 15 articles, in all cases referring to risks to human health or the environment, while 205 articles mentioned benefits. Moreover, thirteen of the fifteen articles that mention risk also mention benefits, indicating that the debate about issues of risk is rather nuanced. Nanotechnology was mainly deemed to have negative consequences for various social groups [Figure 5]. For instance patients or employees were said to be subjected to new health risks when using nanotechnology products. Next to social groups, it was the natural environment that was most often said to suffer from the negative consequences of nanotechnology.

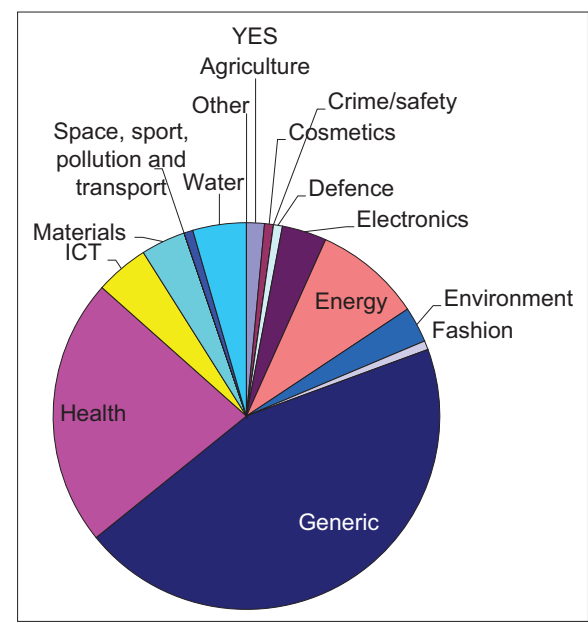

Figure 3: Distribution of articles per domain

Furthermore, we can ask how the public of nanotechnology is framed in the case of negative consequences [Figure 6]. Interestingly, when social groups were mentioned to be at risk, only one-third of the articles framed it as being in need of care. For instance, risks to human health are mentioned in the same article that discusses how nanotechnology can cure cancer. However, the article claims that these risks are minimal because "any nanoparticle which is $<50 \mathrm{~nm}$ size automatically gets filtered through the kidney." ${ }^{[49]}$ While this article notes that nanotechnology may pose risks, no public was constructed because these risks are not so severe that systematic care is required. On the other hand, in those articles where nanotechnology was framed as posing risks for the environment, then four out of five articles mentioned that it required care. Whether or not these risks to the natural environment have consequences for humans was not specified and the natural environment was thus positioned as an actor in itself. Because the natural environment was said to be affected by indirect consequences that are sufficiently important to require care, we can say that in terms of negative consequences, the natural environment comes into being as a public in itself.

Although this finding is in line with the strong focus on health and environmental risks that characterizes nanotechnology politics worldwide, ${ }^{[49]}$ it should be emphasized that these are not the only negative impacts of nanotechnology that could have been highlighted. Literature on nanotechnology and development has for instance repeatedly emphasized the potentially adverse effects of nanotechnology on commodity markets. Nanotechnology may be used to develop cheap alternatives to some expensive minerals that are mostly mined in developing countries, such 
as cold, silver, and copper, thus posing a threat to developing country industries, which in turn may have substantial consequences for people whose income depends on those industries. ${ }^{[0,51]}$ However, remarkably, such concerns play no role whatsoever in the portrayal of nanotechnology in the Times of India. The fact that mineral exports only constitute a small proportion of the Indian industry as compared to other development countries may have contributed to the fact that industry does not emerge as an issue when negative consequences of nanotechnology are concerned.

\section{Positive Consequences}

As was the case with articles discussing risks, the 205 articles discussing positive consequences of nanotechnology mainly focus on social groups [Figure 7]. However, considerable attention is also paid to the positive consequences of nanotechnology for industries and countries $-16 \%$ and $24 \%$ of all articles, respectively. A 2008 article, for example, quotes a company representative claiming that

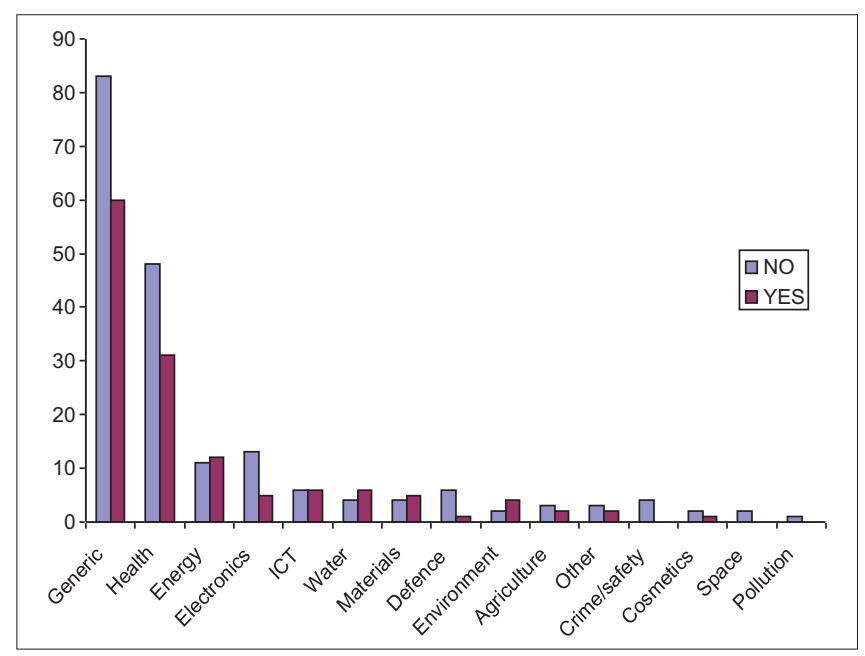

Figure 4: Construction of publics per domain

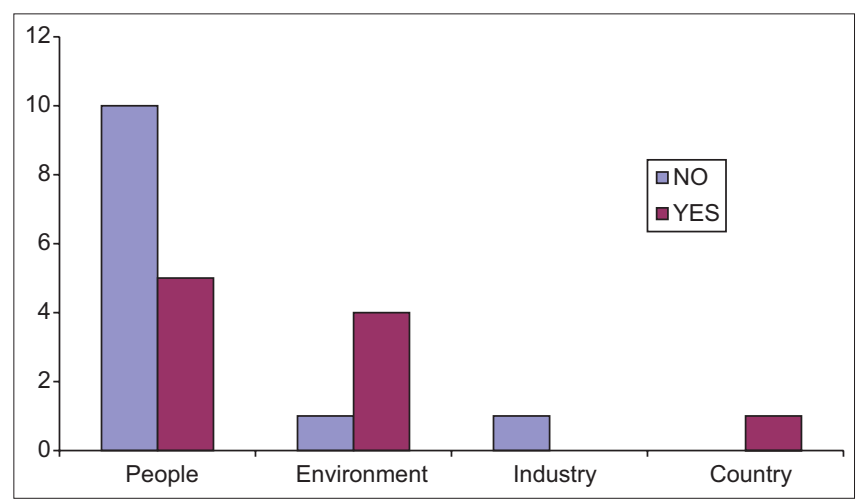

Figure 6: Construction of publics per actor amongst articles with negative consequences their profits can be boosted because nanotechnology can find "significant current or near-term commercial applications" in their products. ${ }^{[52]}$ In contrast to negative impacts, very few articles paid attention to the benefits of nanotechnology for the environment.

When splitting this into whether a public is framed or not, we see that also, in the case of positive consequences, a large share of the public that is constructed consists of various social groups [Figure 8]. For instance, nanotechnology is said to have positive indirect consequences that require care for patients, employees, scientists, or doctors. Interestingly, however, we can see that a public is constructed only less than half of the times that social groups are addressed while when a country was said to be the beneficiary of nanotechnology's consequences, 62 out of 72 times those consequences were described as requiring care as well - hence constructing a public. Clearly, the national interest is something that is considered to be either not

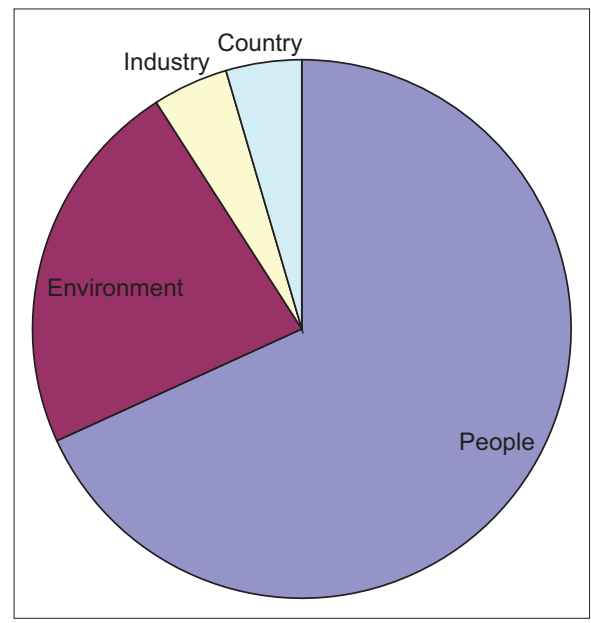

Figure 5: Distribution of negative consequences per actor

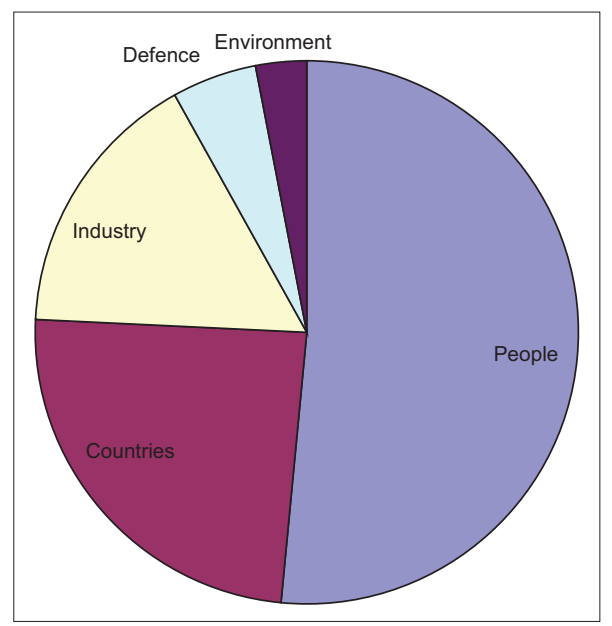

Figure 7: Distribution of positive consequences per actor 


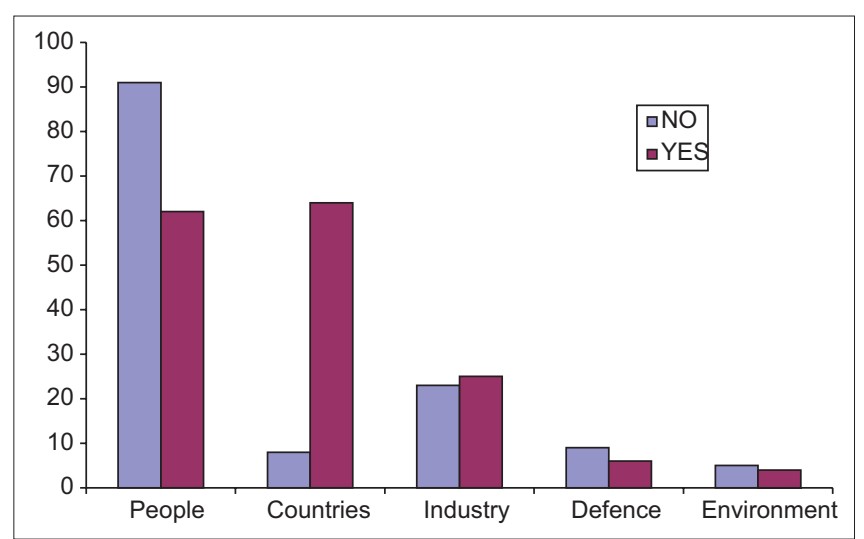

Figure 8: Construction of publics per actor amongst articles with positive consequences

sufficiently taken care of or so important to require extra attention - in either way, the nation appears to be a strong legitimating factor for taking action.

This focus on the consequences of nanotechnology for the nation is further strengthened when categorizing the same articles along geographical lines - for India, foreign countries, and articles that did not specify the geographical area that was said to be affected by the positive consequences of nanotechnology [Figure 9]. The categories "India" and "foreign countries" do not only include articles that mention the countries but also include different types of actors that were specified along geographic lines, such as Indian doctors, Indian scientists, or Israeli companies. Interestingly, when the geographical location of the benefits remained unspecified, almost $60 \%$ of the articles do not give rise to a public, as opposed to little over $20 \%$ when India (or social groups in India) was mentioned. Hence, almost $80 \%$ of the times that India as a country or Indian actors were mentioned to be affected by the positive consequences of nanotechnology, action was said to be required too. In other words, as soon as a nation is mentioned as a beneficiary, then this serves as a justification for action - but only in the case of positive consequences.

This corresponds with earlier findings by this author that the Indian discourse on nanotechnology's benefits is organized along geographical lines, where India is strongly opposed to the rest of the world, in particular to the developed world 45 (Beumer, 2015). Whereas progress in nanotechnology is described as being virtually inevitable, principally due to investments made by developed countries, the ability of India to reap those benefits is described in much more uncertain terms, being conditional upon India's success or failure to take ownership over the technology so that it

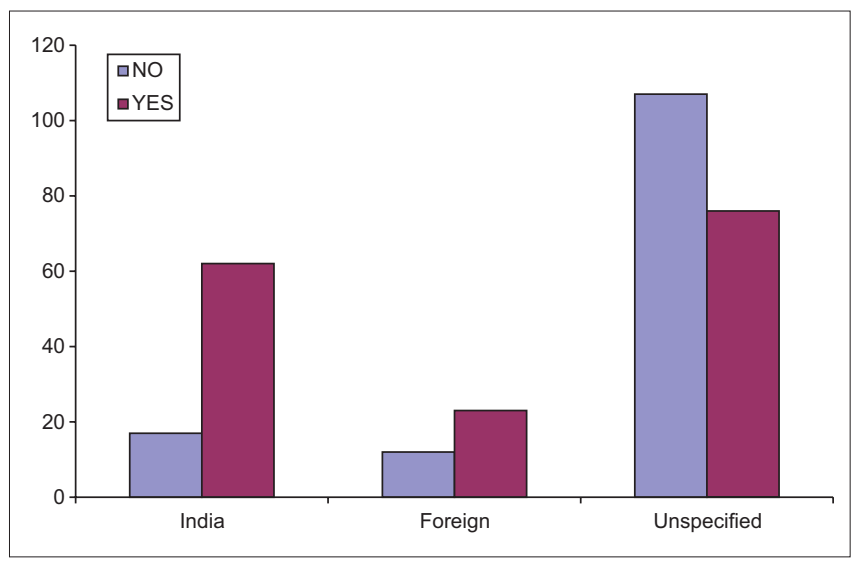

Figure 9: Geographical distribution of positive consequences

can be globally competitive 45 (Beumer, 2015). In a similar fashion, the main issue emerging in the Times of India coverage of nanotechnology is that not enough was done to harness the positive consequences of the technology for India.

\section{CONCLUSIONS}

This article explored the relation between nanotechnology and the public in India by using a concept of the public that diverges from conventional accounts of the public. Rather than assuming the public view coincides with the average opinion of the entire population of a certain territory, this article defined the public as an actor that comes into being as concerns are articulated about the insufficient care for the indirect consequences of a technology. As an experiment, this article has made this notion of the public operational for quantitative analysis by analyzing the co-construction of publics and issues in the Indian newspaper press.

What this analysis shows, first, is that in the Times of India coverage of nanotechnology, a public comes into being that is concerned about missing out on the benefits of nanotechnology. This is in line with theoretical discussions on the "nanodivide." Furthermore, from a Deweyan perspective, this is interesting because it shows that issues that publics do not only emerge in the case to negative consequences. Although some newspaper reports still write that "some of these dangers (of nanotechnology) threaten the very existence of humankind," [53] in the great majority of cases publics are constructed with reference to the benefits: Benefits too require care.

More specifically, the newspaper articles express the view that more care is required for the positive consequences of 
nanotechnology to land in India. The public thus consists predominantly of the nation and social groups from that nation. This may not be a surprising finding since publics are often associated with the nation-state. The fact that the Times of India is distributed nation-wide (instead of internationally or locally) may lead one to expect this. Seen from a constructivist perspective, however, it should be emphasized that the Times of India does not merely confirm the nation to be the primary locus of the public but that it constructs inhabitants of the nation as the relevant public, in turn making technology an important site for nation-building. The issue-based notion of the public allowed for very different outcomes. For instance on the basis of literature on nanotechnology for development, one could expect the poor people in India to be the actor for which the indirect consequences of nanotechnology require care. After all, the literature points out that the poor have a lot to gain and have little means to promote nanotechnology themselves and could thus well in need of some care. Yet, this is clearly not the public that is articulated in the Times of India. Instead, the nation in general takes central stage.

Concerning the downsides, we saw that publics mainly consist of various social groups and of the environment. This is interesting for two reasons. First, because this confirms the objective of this methodology to allow for a heterogeneous public to emerge, the Times of India does not construct a public that necessarily has a shared interest that could give rise to a unified public opinion but constructs multiple publics. And second, it highlights that publics can also consist of nonhuman actors. This was not anticipated before the analysis, but the ability to explicate this type of public can be considered a major benefit of the methodology. Whereas environmental concerns may have been expressed in public engagement activities under study, the environment itself never entered the picture as a public in its own right. The Deweyan concept of the public as those affected by the indirect consequences that are insufficiently cared for, however, opens up conceptual space for the natural environment to come into being as a public. This offers an opportunity to move beyond an ethnocentric approach to the democratization of science and technology.

Scholars have given various names to the attempts to include the voice of the public in the governance of science and technology. Michael and Brown ${ }^{[54]}$ speak of "formalized mechanisms of voicing," Lezaun and Soneryd ${ }^{[55]}$ call these activities "technologies of elicitation," and Laurent ${ }^{[56]}$ calls them "technologies of democracy." This article offers a novel "technology of elicitation" that departs from taken-for-granted notions of the public and instead builds upon a pragmatist concept of the public as an actor that revolves around the issue at hand. By demonstrating that different notions of the public can be made operational for empirical scrutiny, this article contributes to attempts of studies of science and technology to critically engage with democratic theory.

\section{Acknowledgments}

The paper has been developed under the project titled, "Nanotechnologies for development in India, Kenya, and The Netherlands," funded by NWO-WOTRO, The Netherlands.

I would like to express my gratitude to Tsjalling Swierstra, Lucie Dalibert, and Sujit Bhattacharya for their valuable comments. Also, I would like to thank the anonymous reviewers, as well as Wiebe Bijker, Ragna Zeiss, Pankaj Sekhsaria, and Trust Saïdi for their comments on earlier drafts of this paper. All remaining mistakes are entirely mine.

\section{Financial Support and Sponsorship}

\section{NWO-WOTRO.}

\section{Conflicts of Interest}

There are no conflicts of interest.

\section{REFERENCES}

1. Royal Society and Royal Academy of Engineering (RS/RAE). Nanoscience and Nanotechnologies: Opportunities and Uncertainties. Plymouth: Latimer Trend Ltd.; 2004.

2. Wilsdon J, Willis R. See-through Science: Why Public Engagement Needs to Move Upstream. London: Demos; 2004.

3. Irwin A. The politics of talk: Coming to terms with the 'new' scientific governance. Soc Stud Sci 2006;36:299-320.

4. Cobb M, Macoubrie J. Public perceptions about nanotechnology: Risks, benefits and trust. J Nanopart Res 2004;6:395-405.

5. Scheufele D, Lewenstein B. The public and nanotechnology: How citizens make sense of emerging technologies. J Nanopart Res 2005;7:659-67.

6. BMRB. Nanotechnology: Views of the General Public. London: BMRB International Ltd.; 2004. Available from: http://www. nanotec.org.uk/Market\%20Research.pdf. [Last accessed on 2015 Jul 21].

7. Hart PD. Report Findings Based on a National Survey of Adults; 2006. Available from: http://www.nanotechproject.org/ file_download/files/HartReport.pdf. [Last accessed on 2015 Jul 21].

8. Nanopodium. Het Giga Van Nano. Rapport 1-meting Van de Publieke Opinie Over Nanotechnologie; 2010. Available from: 
http://www.nanopodium.nl/CieMDN/content/rapport_1-meting dec2010.pdf. [Last accessed on 2015 Jul 21].

9. Anderson A, Allen S, Petersen A, Wilkinson C. The framing of nanotechnologies in the British newspaper press. Sci Commun 2005;27:200-20.

10. Stephens LF. News narratives about nano S \& T in major U.S. and non-U.S. newspapers. Sci Commun 2005;27:175-99.

11. Cobb MD. Framing effects on public opinion about nanotechnology. Sci Commun 2005;27:221-39.

12. Te Kulve H. Evolving repertoires: Nanotechnology in daily newspapers in the Netherlands. Sci Cult 2006;15:367-82.

13. Gaskell G, Ten Eyck T, Jackson K, Veltri G. Imagining nanotechnology: Cultural support for technological innovation in Europe and the United States. Public Underst Sci 2005; 14:81-90.

14. Faber B. Popularizing nanoscience: The public rhetoric of nanotechnology, 1986-1999. Techn Commun Q 2006;15:141-69.

15. Friedman SM, Egolf BP. Nanotechnology: Risk and the media. IEEE Technol Soc Mag 2005;24:5-11.

16. Weaver DA, Lively E, Bimber B. Searching for a frame: News media tell the story of technological progress, risk, and regulation. Sci Commun 2009;31:139-66.

17. Kjaergaard RS. Making a small country count: Nanotechnology in Danish newspapers from 1996 to 2006. Public Underst Sci 2010;19:80-97.

18. Pidgeon N, Rogers-Hayden T. Opening up nanotechnology dialogue with the publics: Risk communication or 'upstream engagement'? Health Risk Soc 2007;9:191-210.

19. Rogers-Hayden T, Pidgeon N. Moving engagement upstream? Nanotechnologies and the royal society and royal academy of engineering's inquiry. Public Underst Sci 2007;16:345-64.

20. Bowman DM, Hodge GA. Nanotechnology and public interest dialogue: Some international observations. Bull Sci Technol Soc 2007;27:118-32.

21. Stø $E$, Scholl G, Jègou F, Strandbakken $P$. The future of deliberative processes on nanotechnology. In: Von Schomberg R, Davies S, editors. Understanding Public Debate on Nanotechnologies. Options for Framing Public Policy, Luxembourg: Publications Office of the European Union; 2010.

22. Horst M. Public expectations of gene therapy: Scientific futures and their performative effects on scientific citizenship. Sci Technol Human Values 2007;32:150-71.

23. Horst $M$. The laboratory of public debate: Understanding the acceptability of stem cell research. Sci Public Policy 2008;35:197-205

24. Horst M, Irwin A. Nations at ease with radical knowledge. On consensus, consensusing and false consensusness. Soc Stud Sci 2010;40:105-26.

25. Michael M. Publics performing publics: Of PiGs, PiPs and politics. Public Underst Sci 2009;18:617-31.

26. Held D. Models of Democracy. Palo Alto: Stanford University Press; 2006.

27. Felt $U$, Fochler M. Machineries for making publics: Inscribing and de-scribing publics in public engagement. Minerva 2010;48:219-38.

28. Hess DJ. To tell the truth: On scientific counter publics. Public Underst Sci 2011;20:627-41.

29. Marres N. No Issue, No Public: Democratic Deficits After the Displacement of Politics, Dissertation, University of Amsterdam; 2005.

30. Marres N. The issues deserve more credit: Pragmatist contributions to the study of public involvement in controversy. Soc Stud Sci 2007;37:759-80.

31. Dewey J. The Public and its Problems. New York: Swallow Press; 1927.

32. White House. National Nanotechnology Initiative. Leading to the Next Industrial Revolution. White House Press Release; 2000. Available from: http://www.clinton4.nara.gov/WH/New/ html/20000121_4.html. [Last accessed on 2013 Feb 01].

33. Brahic C. Science of the Small Could Create 'Nano-divide'. SciDev.net.; 2004. Available from: http://www.scidev.net/en/news/ science-of-the-small-could-create-nanodivide.html. [Last accessed on 2015 Jul 21].

34. Maclurcan D. Southern roles in global nanotechnology innovation: Perspectives from Thailand and Australia. Nano Ethics 2009;3:137-56.

35. Salamanca-Buentello F, Persad DL, Court EB, Martin DK, Daar AS, Singer PA. Nanotechnology and the developing world. PLoS Med 2005;2:383-6.

36. Juma C, Yee-Cheong L. Innovation: Applying Knowledge in Development. London: Earthscan; 2005.

37. Maclurcan D. Nanotechnology and developing countries. Part 1 : What possibilities? AZojono. J Nanotechnol Online 2005; 1.

38. Zhou P, Leydesdorff L. The emergence of China as a leading nation in science. Res Policy 2006;35:83-104.

39. Kostoff RN, Koytcheff RG, Lau CG. Global nanotechnology research metrics. Scientometrics 2007;70:565-601.

40. Huang C, Notten A, Rasters NJ. Nanoscience and technology publications and patents: A review of social science studies and search strategies. J Technol Transf 2011;36:145-72.

41. Beumer K, Bhattacharya S. Emerging technologies in India: Developments, debates and silences about nanotechnology. Sci Public Policy 2013;40:628-43.

42. Bürgi B, Pradeep T. Societal implications of nanoscience and nanotechnology in developing countries. Curr Sci 2006;90:645-58.

43. Sarma SD. How resilient is India to nanotechnology risks? Examining current developments, capacities and an approach for effective risk governance and regulation. Eur J Law Technol 2011;2:1-15.

44. Sekhsaria $P$. The making of an indigenous scanning tunnelling microscope. Curr Sci 2013;104:1152-8.

45. Beumer K. The co-production of nanotechnology and development in India, South Africa and Kenya. In: Bowman DM, Dijkstra A, Fautz C, Guivant J, Konrad K, Van Lente H et al. editors. Practices of Innovation and Responsibility: Insights from Methods, Governance and Action, Berlin: IOS Press; 2015.

46. Beck U. Risk Society: Towards a New Modernity. London: Sage; 1992.

47. PTI. Kalam Indicates He Isn't Interested in $2^{\text {nd }}$ Term. Times of India; 25, February 2007.

48. Dubey V. Bacteria May Cure Cancer. Times of India. 29, November, 2005.

49. Kjølberg K, Wickson F. Social and ethical interactions with nano: Mapping the early literature. Nano Ethics 2007;1:89-104.

50. Schummer J. The impact of nanotechnologies on developing countries. In: Allhoff F, Lin P, Moor J, Weckert J, editors. Nanoethics: The Ethical and Social Implications of Nanotechnology. Hoboken, NJ: Wiley; 2007.

51. ETC Group. The potential impacts of nano-scale technologies on commodity markets: The implications for commodity dependent developing countries. Geneva: South Centre; 2005.

52. IANS. NRI-owned Firm in UAE Wins NASAAward. Times of India; 23 July, 2008.

53. Sharma M. Small is not Always Beautiful. The Economic Times. 7, December; 2007.

54. Michael M, Brown N. Scientific citizenships: Self-representations of xenotransplantation's publics. Sci Cult 2005;14:38-57.

55. Lezaun J, Soneryd L. Consulting citizens: Technologies of elicitation and the mobility of publics. Public Underst Sci 2007;16:279-97.

56. Laurent B. Technologies of democracy: Experiments and demonstrations. Sci Eng Ethics 2011;17:649-66. 